\title{
A Theoretical Note on the Relationship between Documented and Undocumented Migration
}

\author{
Peter V. Schaeffer ${ }^{1,2}$ and Mulugeta S. Kahsai \\ ${ }^{1}$ Division of Resource Management, West Virginia University, P.O. Box 6201, Morgantown, WV 26506-6201, USA \\ ${ }^{2}$ Regional Research Institute, West Virginia University, P.O. Box 6825, Morgantown, WV 26506-6825, USA
}

Correspondence should be addressed to Peter V. Schaeffer, peter.schaeffer@mail.wvu.edu

Received 9 March 2011; Accepted 18 June 2011

Academic Editor: Rebeca Raijman

Copyright ( 2011 P. V. Schaeffer and M. S. Kahsai. This is an open access article distributed under the Creative Commons Attribution License, which permits unrestricted use, distribution, and reproduction in any medium, provided the original work is properly cited.

\begin{abstract}
Undocumented migration is a (inferior) substitute to documented migration. Hence, policies affecting documented migration also affect undocumented migration. This paper explores this relationship from a theoretical perspective. The implications of this exploration are that lax enforcement of visa rules and national borders, combined with a very long waiting line (small annual quotas) for immigrant visas, can make illegal immigration a preferred option over legal immigration or, more generally, that for policy purposes all types of migrations should be regarded as interdependent. Therefore, policies aimed solely at, say, undocumented immigration will generally be less effective than an integrated policy approach.
\end{abstract}

\section{Introduction}

Mass immigration is a hotly contested topic. Public concerns apply particularly to those who enter or stay without permission, often called undocumented immigrants. This paper studies the relationships between documented (legal) and undocumented (illegal) immigration, and to proceed, we first define who is an immigrant. We exclude short-term foreign business travelers and tourists. It is less obvious how to classify those entering on a student visa and planning to stay for several years. ${ }^{1}$ For a systematic terminology in international migration statistics, see United Nations [1]. For the purpose of this study, we consider as immigrants only those who enter with the intention to work in the host country and plan to stay for the rest of their working life or beyond. We will not separately model all possible migration behaviors. Thus, in this study, we also consider as permanent those immigrants who are itinerant workers who move forth and back repeatedly between the home and the host country, assuming that the majority of their earnings are obtained in the host county.

We assume that here are only two ways to immigrate: legally (DIM) and illegally (UDIM). Under undocumented immigration (UDIM), we understand entry into a country without permission or by ignoring the conditions of a visa to enter, such as staying beyond the expiration of the visa, not reporting to hearings regarding asylum applications [2] or engaging in activities excluded by the visa. The term undocumented can be misleading because the immigrant may have documents but they are either no longer valid, stolen, forged or the holder engages in activities they do not permit $[3,4]$. By documented immigration (DIM) we mean legal entry into a country on a permanent resident visa ("Green Card" in the case of the USA, or a visa, such as an $\mathrm{H}-1 \mathrm{~B}$, that can lead to a green card). A legal immigrant (DIM) may engage in almost all legal activities open to citizens, with the exception of exercising political rights such as voting or holding an elected office ${ }^{2}$, but relatively few other restrictions. They are also eligible for many benefits that are not legally available to UDIM. After a given period of residing in the host country, the legal immigrant usually becomes eligible to apply for citizenship ${ }^{1}$. We assume that individuals assess the immigration opportunities available to them and choose the one offering the highest expected return.

UDIM is an important contributor to total immigration to the USA and many other industrial nations, but with differences. For example, compared to the USA, in the European Union a relatively larger number of UDIM came as asylum 
seekers who stayed even when their request for asylum was denied. Because of open borders between EU member countries, policies need to be coordinated EU-wide. Guild et al. [5-7], Albrecht [8], and Carrero and Merlino [9] offer a review and discussion of European legal and policy perspectives. In the USA, a study prepared by the US Congressional Research Service lists an estimated 12 million individuals as present without authorization [4], which is similar to the figure reported by Passel and Cohn [10]. In 2008, the US labor force of 154 million included 8.3 million UDIM, or about $5.4 \%$ of the civilian labor force ([11]; for 2002 estimates see [12]). Immigration reform has proven to be difficult, as failed attempts by the G.W. Bush administration demonstrated. For a short while, the priority given to immigration reform by the American public seemed to have decreased, though it still ranked high $[13,14]$, but high unemployment and a slow recovery from the 2008 recession have moved it up again on the public's agenda [15]. For several decades, in the first half of the 20th century, the USA pursued a restrictive immigration policy that also favored "traditional" European immigrants. This changed with immigration reform that became effective in 1965 . Although there have been additional changes to immigration law [15], the renewed immigration and, particularly, the much greater number of non-European immigrants can be traced back to the 1965 changes. For a review of UDIM policy in the USA from 1921 to 1965, see Ngai [16], and for a discussion of recent attempts at immigration reform and the relationship to labor shortages, see Martin and Ruhs [17]. Finally, Steinhardt [18] provides a recent study of the wage impact of immigrants to Germany on natives with similar qualifications.

Immigration reform is costly. The US Congressional Budget Office estimated that the proposed Comprehensive Immigration Reform Act of 2006 would have increased direct federal spending by $\$ 13$ billion over the period 2007-2011 and by $\$ 54$ billion over the period 2007-2016 [19]. For a recent discussion of the impacts of mass immigration in other countries, see Grubel [20]. For an early theoretical analysis of the fiscal impact of mass immigration at different levels of government, see Schaeffer [21], and for an earlier discussion of illegal immigration, see Hewlett [22], and Morris and Mayio [23]. The following articles provide a brief overview of major current topics regarding immigration, particularly in the USA: Borjas [24], Auerbach and Oreopoulos [25], Lee and Miller [26], Storesletten [27], Camarota [28], Cornelius [29], Espenshade [30], and Hanson [31]. It would be a mistake, however, to assume that illegal immigration is primarily a problem of the traditional immigration countries, as recent immigration nations, such as Italy and Spain, illustrate [32-35].

Not all immigrants enter the host country under the same conditions and with the same rights. For example, the USA has several categories of family-sponsored or employmentbased paths to an immigrant visa (green card). ${ }^{3}$ Other categories include refugees, political asylum seekers, and, in the USA, the Diversity Immigrant Visa, better known to the general public under the name visa lottery. Applicants under each category face different probabilities of success. They also have to wait for different lengths of time before they are allowed to enter, once their immigrant visa is approved. ${ }^{4}$ We also note that eligibility for some, but not all, categories is mutually exclusive, so that some applicants must choose which program to apply to while others may have no choice except a very long expected wait for a visa or undocumented entry. In this paper we consider home country conditions that contribute to the propensity to emigrate only implicitly, by focusing on those individuals who are expected to improve their well-being by moving to another country. Home country conditions' impact on emigration in the case of Mexico is discussed in Pew Global Project [36].

The basic logic of the theoretical model follows that of Schaeffer [37] as applied by Schaeffer and Kahsai [38] to study the $\mathrm{H}-1 \mathrm{~B}$ visa program in the USA. An alternative approach could use the Harris-Todaro model [39] or its more general version [40]. This paper also differs from Ethier's work [41], which focuses on the relationships between the wage of illegal immigrants, the taxes they contribute, and border enforcement. While Ethier's model is more general in representing illegal migration than ours, he does not address the issue of legal versus illegal immigration, which is the focus of this research.

The remainder of this paper is organized as follows. In Section 2 we present the model in graphical form and derive first implications, and in Section 3, we extend the model. Section 4 concludes the paper and provides a summary of findings and conclusions.

\section{The Model}

Since both DIM and UDIM lead to immigration in the desired destination country, they can be regarded as substitutes for each other, a point made clear by Orrenius: "In the United State (and many other countries), simply restricting immigration to below the global demand for visas creates an incentive for foreigners to illegally immigrate ([42]; see also [43])." The two types of immigration are imperfect substitutes, however, since legal immigrants enjoy many more rights and privileges than illegal immigrants who have a tenuous legal status. Therefore, there is little doubt that if DIM were freely available, there would be no UDIM. Not all prospective immigrants face the same probability of being granted a permanent immigrant visa. In the USA and most other countries, the foreign spouse of a citizen has an excellent chance to qualify and would, therefore, be ill advised to choose illegal immigration as an alternative. A very highly skilled individual might have a good chance at a permanent visa to the USA via the $\mathrm{H}-1 \mathrm{~B}$ program [38], or similar program for immigration to other countries. A number of countries provide preferential treatment to affluent immigrants. In the USA, for example, the EB-5 program is for immigrants who commit themselves to invest at least \$1 million, or \$0.5 million if the investment is made in a targeted employment area [44]. Unskilled immigrants of small means are excluded from such opportunities. Even if they qualify for a family-based program, the queue and, therefore, the wait may be so long as to make UDIM the more attractive alternative. 
Figure 1 represents the choice between DIM and UDIM. We assume that the household maximizes utility. For simplicity, we express utility as a function of income only. In reality, many more factors than income are considered in making location and work decisions (e.g., Pew Global Project [36]). We shall therefore regard the utility as a measure of the comparative well-being of individuals, subject to their migration choice (or choice not to migrate), and their success in entering the host country and being able to stay there. Thus, the prospective migrant compares the following two expected outcomes:

$$
\begin{aligned}
& E\left[U_{\text {DIM }}\right]=p_{\text {DIM }} U\left(Y_{\text {DIM }}\right)+\left(1-p_{\text {DIM }}\right) U\left(Y_{\mathrm{NM}}\right), \\
& E\left[U_{\text {UDIM }}\right]=p_{\text {UDIM }} U\left(Y_{\text {UDIM }}\right)+\left(1-p_{\text {UDIM }}\right) U\left(Y_{\mathrm{NM}}\right) .
\end{aligned}
$$

$E\left[U_{\text {DIM }}\right]$ and $E\left[U_{\text {UDIM }}\right]$ denote the expected utilities in the case of documented (legal) and undocumented (illegal) immigration, respectively. Similarly, $p_{\text {DIM }}$ and $p_{\text {UDIM }}$ are the respective probabilities of successful legal and successful illegal immigration. $Y_{\text {DIM }}$ and $Y_{\text {UDIM }}$ are the incomes of documented and undocumented immigrant households, respectively. We assume that $Y_{\text {UDIM }}<Y_{\text {DIM }}$ because undocumented immigrants face more labor market constraints than legal immigrants. The subscript NM stands for "no migration" and $Y_{\mathrm{NM}}$ is the household income when migration is not successful or not attempted. In this section, we also assume that illegal immigration precludes any possibility of legal immigration. This specifically excludes the possibility of an immigration amnesty. We will relax this assumption in Section 3. Finally, we start our analysis assuming that $p_{\text {DIM }}<$ $p_{\text {UDIM }}$, since otherwise there would be no undocumented immigration. We interpret $1-p_{\text {UDIM }}$ as the probability of an unsuccessful attempt at illegal immigration, regardless of whether individuals fail to make it across the border or succeed but are discovered and deported. A survey among Hispanic residents in the USA revealed that $53 \%$ of them worry about being deported; the percentages are $67 \%$ among foreign-born Hispanics and 32\% among native born [45]. The impact of apprehension on migration behaviors is discussed in [46].

Figure 1 is drawn such that $E\left[U_{\text {DIM }}\right]<E\left[U_{\text {UDIM }}\right]$. Given the assumption we made, this outcome is likely if puDIM $p_{\text {DIM }}>0$ and large enough to compensate migrants who choose UDIM for the lower household income relative to migrants with identical qualification who choose DIM. The outcome is also possible if $p_{\text {UDIM }}-p_{\text {DIM }}$ is small as long as $Y_{\text {DIM }}-Y_{\text {UDIM }}$ is also small ${ }^{5}$. This latter situation could occur if there is no penalty for, and/or lack of effective enforcement against, employers who hire UDIMs.

One obvious implication is that a very restrictive legal immigration policy combined with lax enforcement of immigration laws increases the attractiveness of illegal immigration. In a legal environment that favors the highly skilled and/or the affluent, this also implies that the illegal immigrants are more likely to be low skilled and/or poor relative to their legal counterparts, since the latter often have

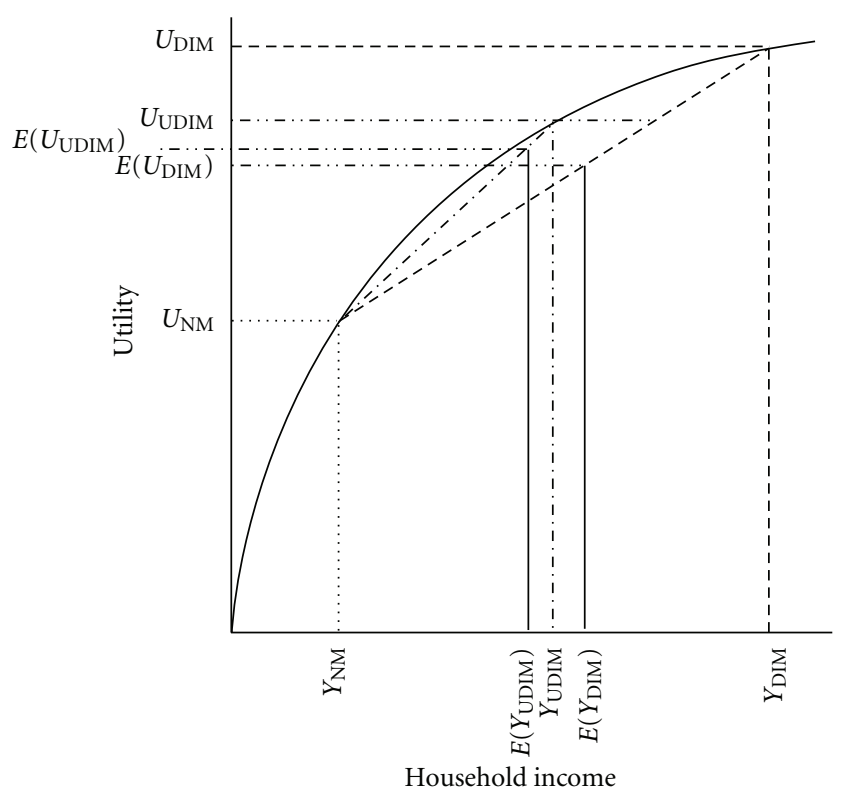

Figure 1: The choice between DIM and UDIM.

superior opportunities available to them. It follows from (1a) and $(1 \mathrm{~b})$ that if $p_{\text {DIM }} U\left(Y_{\text {DIM }}\right)+\left(1-p_{\text {DIM }}\right) U\left(Y_{\mathrm{NM}}\right)=$ $p_{\text {UDIM }} U\left(Y_{\text {UDIM }}\right)+\left(1-p_{\text {UDIM }}\right) U\left(Y_{\text {NM }}\right)$, then the prospective immigrant is indifferent between DIM and UDIM. This condition can be rewritten as

$$
p_{\text {UDIM }}-p_{\text {DIM }}=p_{\text {UDIM }} \frac{U\left(Y_{\text {UDIM }}\right)}{U\left(Y_{\mathrm{NM}}\right)}-p_{\text {DIM }} \frac{U\left(Y_{\text {DIM }}\right)}{U\left(Y_{\mathrm{NM}}\right)}{ }^{6}
$$

The first fraction on the RHS of (2) is the relative gain in utility from undocumented immigration and the second fraction that from document immigration. If LHS > RHS, then the prospective immigrant prefers DIM to UDIM. If the inequality is reversed, the preference is also reversed. Clearly, equilibrium is possible only if either $Y_{\text {DIM }}>Y_{\text {UDIM }}$ and $p_{\text {DIM }}<p_{\text {UDIM }}$ or if $Y_{\text {DIM }}<Y_{\text {UDIM }}$ and $p_{\text {DIM }}>p_{\text {UDIM }}$. The second set of conditions is very unlikely to occur in reality, so that only the first set is of practical interest. For any prospective migrant, if both inequalities point in the same direction, then either DIM or UDIM is the dominant choice.

The concavity of the utility function assumes that individuals are risk averse. The approximate probabilities used for obtaining the expected values are $p_{\text {DIM }} \approx 0.5$ and $p_{\text {UDIM }} \approx 0.85$, respectively. However, as Figure 1 shows, individuals who are risk averse consider not only the expected outcomes, $E\left[U_{\text {DIM }}\right]$ and $E\left[U_{\text {UDIM }}\right]$, respectively, but also the expected time before they achieve their goal of immigration. In the case of legal immigration, the expected time until the prospective immigrant receives the visa is given by $E\left[\Lambda_{\text {DIM }}\right]=\sum_{t=1}^{\infty} t p_{\text {DIM }}\left(1-p_{\text {DIM }}\right)^{t-1}=1 / p_{\text {DIM }}$. On average, successful migration takes the illegal immigrant less time, namely, $E\left[\Lambda_{\text {UDIM }}\right]=\sum_{t=1}^{\infty} t p_{\text {UDIM }}\left(1-p_{\text {UDIM }}\right)^{t-1}=$ $1 / p_{\text {UdIM }} . E\left[\Lambda_{\text {DIM }}\right]>E\left[\Lambda_{\text {UDIM }}\right]$ because $P_{\text {DIM }}<P_{\text {UDIM }}$. Thus, although in the destination country illegal immigrants earn less than similarly qualified legal immigrants, the former can expect to earn higher wages than those paid in the origin 
country for a longer time than the latter, which could be enough to compensate for the wage advantage that comes with legal migration.

We can also express the standard deviations of $\Lambda_{\text {DIM }}$ and $\Lambda_{\text {UDIM }}$, respectively, $\sigma\left(\Lambda_{\text {DIM }}\right)=\sqrt{1-p_{\text {DIM }}} / p_{\text {DIM }}$ and $\sigma\left(\Lambda_{\text {UDIM }}\right)=\sqrt{1-p_{\text {UDIM }}} / p_{\text {UDIM }}$. Since, by assumption, $p_{\text {UDIM }}>p_{\text {DIM }}$, we conclude that $\sigma\left(\Lambda_{\text {DIM }}\right)>\sigma\left(\Lambda_{\text {UDIM }}\right)$. Thus, in terms of variability of outcomes, illegal immigration is less risky than legal immigration under the assumption that $p_{\text {UDIM }}>p_{\text {DIM }}$. Of course, this conclusion does not consider all risks associated with illegal migration. Nonetheless, everything else being held equal, risk averse individuals are more likely to choose illegal immigration if the combined probability of successfully crossing the border and remain in the destination country undetected is large relative to the probability of obtaining a visa for legal immigration.

\section{Amnesty}

In this section, we relax the assumption that undocumented immigration forever precludes the possibility of becoming a documented immigrant by allowing for an immigration amnesty that opens up a path for UDIMs to legalize their status. Mathematically, this can be stated as follows:

$$
\begin{gathered}
E\left[U_{\text {DIM }}\right]=p_{\text {DIM }} U\left(Y_{\text {DIM }}\right)+\left(1-p_{\text {DIM }}\right) U\left(Y_{\mathrm{NM}}\right), \\
E\left[U_{\text {UDIM }}\right]=p_{\text {UDIM }}\left\{p_{\text {AMN }} U\left(Y_{\text {DIM }}\right)+\left(1-p_{\text {AMN }}\right) U\left(Y_{\text {UDIM }}\right)\right\} \\
+\left(1-p_{\text {UDIM }}\right) U\left(Y_{\mathrm{NM}}\right),
\end{gathered}
$$

where $p_{\text {AMN }}$ is the probability of an amnesty. Equation (3a) is a restatement of (1a), but (3b) is changed from (1b). Without the possibility of amnesty, the prospective immigrant had only two possible outcomes to consider: one in which the household earned the income $Y_{\text {UDIM }}$ and the other in which the income was $Y_{\mathrm{NM}}$. With amnesty, a third possible outcome, $Y_{\mathrm{DIM}}$, has a positive probability, $p_{\text {UDIM }} p_{\text {AMN }}$. The probability of outcome $Y_{\mathrm{NM}}$ is unchanged, and the probability of $Y_{\text {UDIM }}$ is reduced by the factor $p_{\text {AMN }}$. Since $Y_{\text {DIM }}>$ $Y_{\text {UDIM }}$ by assumption, amnesty makes UDIM more attractive and the increased attraction is positively related to the value of $p_{\text {AMN }}$.

The possibility of amnesty is included in the revised graphical representation of the model in Figure 2. Although we made UDIM without amnesty less attractive than we did in Figure 1, the addition of amnesty resulted once again in a situation in which UDIM would be preferred to DIM. The larger the value of $p_{\mathrm{AMN}}$ is, the more attractive UDIM will be relative to DIM.

To further illustrate the tradeoff between the two choices, let us look at the expected length of time before a prospective immigrant will have achieved legal immigrant status. In the case of the DIM, this is given by

$$
E\left[\Lambda_{\mathrm{DIM}}\right]=\sum_{t=1}^{\infty} t p_{\mathrm{DIM}}\left(1-p_{\mathrm{DIM}}\right)^{t-1}=\frac{1}{p_{\mathrm{DIM}}} .
$$

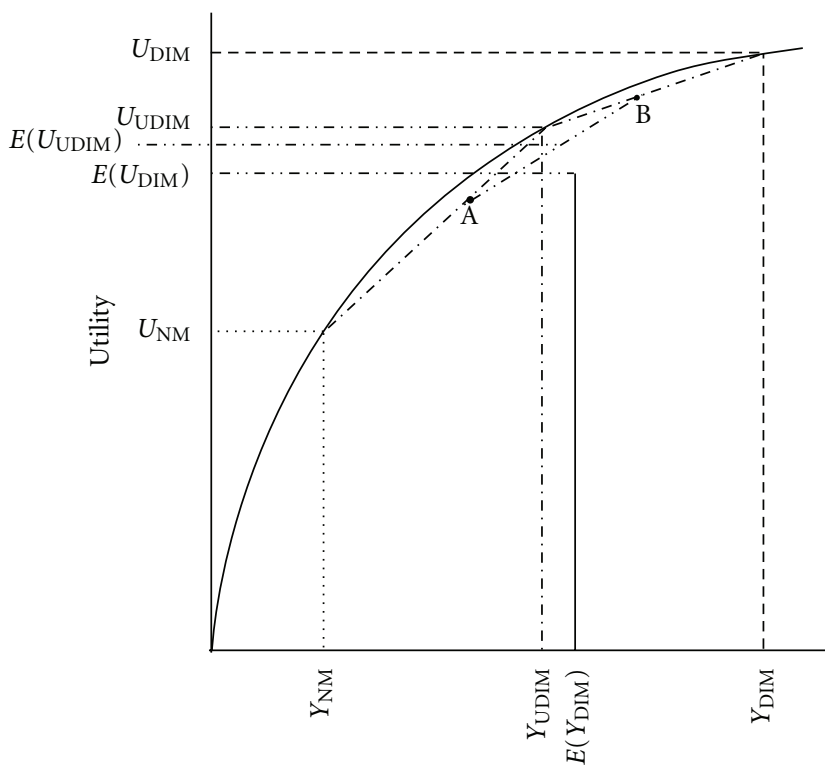

Household income

FIGURE 2: The choice between DIM and UDIM when amnesty if possible.

We assume that the length of period $t$ is 1 . For the individual who chooses UDIM, the expected time until legal status is obtained as

$$
\begin{gathered}
E\left[\Lambda_{\mathrm{DIM}}^{\mathrm{UDIM}}\right]=\sum_{t=1}^{\infty} t p_{\mathrm{UDIM}} p_{\mathrm{AMN}}\left(1-p_{\mathrm{UDIM}} p_{\mathrm{AMN}}\right)^{t-1} \\
=\frac{1}{p_{\mathrm{UDIM}} p_{\mathrm{AMN}}} .
\end{gathered}
$$

The expected length of time until legal permanent residency status (DIM) is obtained as the same for DIM and UDIM if $E\left[\Lambda_{\text {DIM }}\right]=E\left[\Lambda_{\text {DIM }}^{\mathrm{UDIM}}\right] \Leftrightarrow 1 / p_{\text {DIM }}=1 / p_{\text {UDIM }} p_{\text {AMN }}{ }^{7}$

Indifference requires that one of the following three conditions must be met:

(a) $E\left[U\left(Y_{\mathrm{DIM}}\right)\right]=E\left[U\left(Y_{\mathrm{UDIM}}\right)\right]$ and $E\left[\Lambda_{\mathrm{DIM}}\right]=E\left[\Lambda_{\mathrm{DIM}}^{\mathrm{UDIM}}\right]$,

(b) $E\left[U\left(Y_{\text {DIM }}\right)\right]>E\left[U\left(Y_{\text {UDIM }}\right)\right]$ and $E\left[\Lambda_{\text {DIM }}\right]>E\left[\Lambda_{\text {DIM }}^{\mathrm{UDIM}}\right]$,

(c) $E\left[U\left(Y_{\mathrm{DIM}}\right)\right]<E\left[U\left(Y_{\mathrm{UDIM}}\right)\right]$ and $E\left[\Lambda_{\mathrm{DIM}}\right]<E\left[\Lambda_{\mathrm{DIM}}^{\mathrm{UDIM}}\right]$.

The indifference between legal and illegal migration in case (a) is obvious. Case (b) states that if the expected utility of legal immigration exceeds that of illegal immigration, then to compensate for the lower expected utility of UDIM, the expected length of time before the immigrant becomes a legal resident through amnesty must be shorter than the expected length of time before an applicant for an immigration visa is successful. Case (c) is impossible as long as $Y_{\text {DIM }} \geq Y_{\text {UDIM }}$, because the first inequality implies $p_{\text {DIM }}<p_{\text {UDIM }}$ while the second inequality implies the opposite. Thus, it plays no role in policy practice.

We can take the analysis one step further and look at the standard deviation of the expected time before legal permanent residence status is realized. The standard deviations for 
DIM and UDIM, with the possibility of amnesty, are given in (5).

$$
\begin{gathered}
\sigma\left(\Lambda_{\mathrm{DIM}}\right)=\frac{\sqrt{1-p_{\mathrm{DIM}}}}{p_{\mathrm{DIM}}}, \\
\sigma\left(\Lambda_{\mathrm{DIM}}^{\mathrm{UDIM}}\right)=\frac{\sqrt{1-p_{\mathrm{UDIM}} p_{\mathrm{AMN}}}}{p_{\mathrm{UDIM}} p_{\mathrm{AMN}}} .
\end{gathered}
$$

From the discussion following (4a) and (4b) and from (5), it follows that

$$
E\left[\Lambda_{\mathrm{DIM}}\right]=E\left[\Lambda_{\mathrm{DIM}}^{\mathrm{UDIM}}\right] \Longleftrightarrow \sigma\left(\Lambda_{\mathrm{DIM}}\right)=\sigma\left(\Lambda_{\mathrm{DIM}}^{\mathrm{UDIM}}\right) .
$$

Thus, there is no need to amend the discussion of the conditions of indifference between DIM and UDIM when amnesty has a positive probability.

\section{Discussion and Conclusions}

We started by noting that documented and undocumented immigration are substitutes. We presented a simple model of immigration to compare the tradeoff between documented and undocumented migration into a country. If there are no constraints on immigration, documented (legal) immigration is strictly preferred. However, we showed that there are sound theoretical reasons to expect that individuals could find UDIM an attractive alternative to DIM if permits for the latter are hard to obtain while at the same time border and immigration law enforcement is lax. For prospective immigrants with privileged access to DIM visas, however, UDIM may always be unattractive. Since the privileged groups include the affluent and the highly skilled, we can conclude that the poor and unskilled will be overrepresented among the UDIMs. All of these conclusions agree with empirical facts though empirical analysis requires data that are difficult to obtain or unavailable. Because of the uncertainty associated, particularly with illegal immigration, our analysis suggests that immigrants tend to be less risk averse than otherwise identical individuals who stay behind.

In general, this theoretical note suggests that immigration policy must be comprehensive to be effective, a conclusion also reached by Ethier [41] and Schaeffer [47]. That is, policy must consider the impact of one program-for example, one that privileges the affluent-on the demand for other programs and on UDIM. This research also reinforces what intuition tells us, namely, that policies and enforcement efforts must be coordinated. The level of enforcement that is sufficient to reduce UDIM to a politically and socially acceptable level is not constant but depends on the ease with which permanent legal residence visas can be obtained $\left(p_{\text {DIM }}\right)$. In the extreme case of $p_{\text {DIM }}=1$, no enforcement against UDIM is necessary because no rational individual would choose it. Conversely, a country that has a very restrictive immigrant policy must also have rigorous border and immigrant law enforcement.

\section{Acknowledgments}

The authors acknowledge support for this research from the West Virginia Agricultural and Forestry Experiment Station and from the Regional Research Institute, West Virginia University.

\section{Endnotes}

1. A comparison of the definitions of "immigrant alien" by the Department of Homeland Security versus that of "tax resident alien" by the US Internal Revenue Service reveals that the latter is much broader and includes students, among others. See http://www.irs.gov/businesses/small/international/article/0,,id=96493,00.html and http://www.irs.gov/taxtopics/tc851.html for more detailed information that shows some ambivalence regarding who is a resident with obligations towards the host country, versus a visitor with few obligations beyond law abidance.

2. Citizens of EU members who immigrate to another EU member country, even, have the right to participate and run for office in local elections in the host country. Since citizens of EU member countries are also citizens of the $\mathrm{EU}$, the concept of "foreign" immigrant is ambivalent in the case of intra-EU migration.

3. The complete list of categories in the USA is available in the document SI 00502.215, The Affidavits of Support, Social Security Administration, https://secure .ssa.gov/apps10/poms.nsf/lnx/0500502215\#C.

4. In the USA, several family-sponsored categories have backlogs of up to 10 years. The category for spouses of legal permanent residents has a backlog of 4 to 5 years. By contrast, only one of the employment-based categories had a backlog in 2009.

5. In agricultural employment, Pena [48] finds a wage difference between legal and illegal immigrants of "only" $6 \%$ to $7 \%$. A bigger difference exists in the use of government aid programs. She concludes from her analysis that an amnesty for farm workers would have a minimal impact on workers' outcomes or on food prices in the USA.

6. A numerical example may help illustrate the relationship (without amnesty). Let $P_{\mathrm{UDIM}}=0.5$ and $P_{\mathrm{DIM}}=$ 0.1 . Assume that $U\left(Y_{\text {UDIM }}\right)=1.2 U\left(Y_{\mathrm{NM}}\right)$. Then, $(2)$ says that a prospective immigrant is indifferent between DIM and UDIM if $U\left(Y_{\text {DIM }}\right)=3.0 U\left(Y_{\mathrm{NM}}\right)$.

7. If we let $p_{\text {UDIM }}=0.5$ and $p_{\text {DIM }}=0.1$ as in footnote 3 , then $E\left[\Lambda_{\mathrm{DIM}}\right]=10 . E\left[\Lambda_{\mathrm{UDIM}}\right]=10$ if and only if $p_{\mathrm{AMN}}=0.2$; that is, if amnesty is granted every five years, on average. However, note that for these three values $E\left[U\left(Y_{\text {UDIM }}\right)\right]<E\left[U\left(Y_{\text {DIM }}\right)\right]$, so that DIM would be preferred to UDIM. The determination of the exact point of indifference is impossible without specifying the functional form of the utility. 


\section{References}

[1] United Nations, "Recommendations on Statistics of International Migration: Revision 1," Statistical Paper Series M, no. 58, Department of Economic and Social Affairs, Statistics Division, United Nations, New York, NY, USA, 1998.

[2] R. M. Stana, Illegal Aliens: INS' Process for Denying Aliens Entry Into the United States, General Accounting Office, Testimony before the Permanent Subcommittee on Investigations, Committee on Governmental Affairs, U.S. Senate, Washington, DC, USA, 2001.

[3] R. W. Mortensen, Illegal but not Undocumented: Identity Theft, Document Fraud, and Illegal Employment, Center for Immigration Studies, Washington, DC, USA, 2009, http://cis.org/ IdentityTheft.

[4] R. E. Wasem, "Immigration fraud: policies, investigations, and issues," CRS Report for Congress RL34007, Congressional Research Service, Washington, DC, USA, 2007.

[5] E. Guild, S. Carrero, and A. Eggenschwiler, Informing the Asylum Debate, Center for European Policy Studies, Brussels, Belgium, 2009, http://www.ceps.eu/book/informing-asylumdebate.

[6] E. Guild, S. Carrero, and A. Eggenschwiler, Informing the Border Debate, Center for European Policy Studies, Brussels, Belgium, 2009, http://www.ceps.eu/book/informing-bordersdebate.

[7] E. Guild, S. Carrero, and A. Eggenschwiler, Informing the Immigration Debate, Center for European Policy Studies, Brussels, Belgium, 2009, http://www.ceps.eu/book/informing-immigration-debate.

[8] H.-J. Albrecht, "Fortress Europe? Controlling illegal immigration," European Journal of Crime, Criminal Law and Criminal Justice, vol. 10, no. 1, pp. 1-22, 2002.

[9] S. Carrero and M. Merlino, "Undocumented immigrants and rights in the EU: addressing the gap between social science research and policy-making in the Stockholm programme?" Center for European Policy Studies, Brussels, Belgium, 2009, http:// www. ceps.eu/book/ undocumented-immigrants - andrights-eu-addressing-gap-between-social-sciences - research and-polic.

[10] J. S. Passel and D. Cohn, Trends in Unauthorized Immigration: Undocumented Inflow Now Trails Legal Inflow, Report, Pew Hispanic Center, Washington, DC, USA, 2008, http://pewhispanic.org/files/reports/94.pdf.

[11] J. S. Passel and D. Cohn, "A portrait of unauthorized immigrants in the United States," Report, Pew Hispanic Center, Washington, DC, USA, 2009, http://pewhispanic.org/files/reports/107.pdf.

[12] J. S. Passel, R. Capps, and M. Fix, "Undocumented immigrants: facts and figures," Health Policy Center, Urban Institute, Washington, DC, USA, 2004, http://www.urban.org/ health_policy/url.cfm?ID=1000587.

[13] S. Keeter, Where the Public Stands on Immigration Reform, Pew Center for the People \& the Press. Pew Research Center Publications, Washington, DC, USA, 2009, http://pewresearch .org/pubs/1421/where-the-public-stands-on-immigration-reform.

[14] T. G. Tancredo, A New Strategy for Control of Illegal Immigration, Heritage Lectures no. 971, The Heritage Foundation, Washington, DC, USA, 2006.

[15] G. Facchini and M. F. Steinhardt, "What drives U.S. immigration policy? Evidence from congressional roll call votes," Journal of Public Economics, vol. 95, no. 7-8, pp. 734-743, 2011.
[16] M. M. Ngai, "The strange career of the illegal alien: immigration restriction and deportation policy in the United States, 1921-1965," Law and History Review, vol. 21, no. 1, pp. 69$107,2010$.

[17] P. Martin and M. Ruhs, "Labor shortages and U.S. immigration reform: promises and perils of an independent commission," International Migration Review, vol. 45, no. 1, pp. 174187, 2011.

[18] M. F. Steinhardt, "The wage impact of immigration in Germany-new evidence for skill groups and occupations," The B.E. Journal of Economic Analysis \& Policy, vol. 11, no. 1, article 31, 2011.

[19] Congressional Budget Office, Congressional Budget Office Cost Estimate: S.2611 Comprehensive Immigration Reform Act of 2006: As Introduced on April 7, 2006, Congressional Budget Office, Washington, DC, USA, May 2006, submitted to Senator Grassley, Chairman, Committee of Finance, U.S. Senate.

[20] H. Grubel, Ed., The Effects of Mass Immigration on Canadian Living Standards and Society, The Fraser Institute, Calgary, Canada, 2009.

[21] P. V. Schaeffer, "Immigration into the United States: an important issue for state and local governments," Planning and Public Policy, vol. 9, no. 1, pp. 1-3, 1983.

[22] S. A. Hewlett, "Coping with illegal immigrants," Foreign Affairs, vol. 60, no. 2, pp. 358-378, 1981.

[23] M. D. Morris and A. Mayio, Curbing Illegal Immigration, Brookings Institution, Washington, DC, USA, 1982.

[24] G. Borjas, “The economic benefits from immigration," Journal of Economic Perspectives, vol. 9, no. 2, pp. 3-22, 1995.

[25] A. J. Auerbach and P. Oreopoulos, "Analyzing the fiscal impact of U.S. immigration," American Economic Review, vol. 89, no. 2, pp. 176-180, 1999.

[26] R. Lee and T. Miller, "New issues in immigration: immigration, social security, and broader fiscal impacts," American Economic Review, vol. 90, no. 2, pp. 350-354, 2000.

[27] K. Storesletten, "Sustaining fiscal policy through immigration," Journal of Political Economy, vol. 108, no. 2, pp. 300-323, 2000.

[28] S. A. Camarota, "The high cost of cheap labor: illegal immigration and the federal budget," Paper no. 1-881290-43-3, Center for Immigration Studies, Washington, DC, USA, 2004, http://www.cis.org/articles/2004/fiscal.pdf.

[29] W. A. Cornelius, "Controlling "unwanted" immigration: lessons from the United States, 1993-2004," Journal of Ethnic and Migration Studies, vol. 31, no. 4, pp. 775-794, 2005.

[30] T. J. Espenshade, "Unauthorized immigration to the United States," Annual Review of Sociology, vol. 21, pp. 195-216, 1995.

[31] G. H. Hanson, "The economic logic of illegal immigration," Council Special Report 26, Council for Foreign Relations, New York, NY, USA, 2007.

[32] L. Abend and A. Momigliano, "Spain, Italy: two tactics for tackling illegal immigration," Christian Science Monitor, August 2008 .

[33] V. Burnett, "To curb illegal migration, Spain offers a legal route," The New York Times, August 2007.

[34] "Migration: character and scope, economic potential, regional perspectives," in The Forum: Discussing International Affairs and Economics, Center for International Relations, Ed., pp. 3133, Center for International Relations, 2010, http://www.iaforum.org/.

[35] S. Strozza, "Estimates of the illegal foreigners in Italy: a review of the literature," International Migration Review, vol. 38, no. 1, pp. 309-331, 2004. 
[36] Pew Global Project, Troubled By Crime, The Economy, Drugs and Corruption Most Mexicans See Better Life In U.S.-Onein-Three Would Migrate, Pew Research Center, Pew Global Project-Attitudes, Washington, DC, USA.

[37] P. V. Schaeffer, "Human capital, migration strategy, and brain drain," Journal of International Trade and Economic Development, vol. 14, no. 3, pp. 319-335, 2005.

[38] P. V. Schaeffer and M. S. Kahsai, "Evaluating the H-1B visa program: theoretical issues," China-USA Business Review, vol. 8, no. 11, pp. 44-54, 2009.

[39] J. R. Harris and M. P. Todaro, "Migration, unemployment, and development: a two-sector analysis," American Economic Review, vol. 60, pp. 126-142, 1976.

[40] P. V. Schaeffer, "Barriers and foresight in international labormigration," Environment \& Planning A, vol. 16, no. 4, pp. 451466, 1984.

[41] W. J. Ethier, "Illegal immigration: the host-country problem," American Economic Review, vol. 76, no. 1, pp. 56-71, 1986.

[42] P. M. Orrenius, "Illegal immigration and enforcement along the U.S.-Mexico border: an overview," Economic and Financial Review, pp. 2-11, 2001.

[43] J. R. Edwards Jr., Two Sides of the Same Coin: The Connection Between Legal and Illegal Immigration, Center for Immigration Studies, Washington, DC, USA, 2006, http://www.cis.org/articles/2006/back106.pdf.

[44] USCIS, EB-5 Immigrant Investor, United States Citizenship and Immigration Services, Washington, DC, USA, 2009, http://www.uscis.gov/portal/site/uscis/menuitem.eb1d4c2a3e 5b9ac89243c6a7543f6d1a/?vgnextoid=facb83453d4a3210Vgn VCM100000b92ca60aRCRD\&vgnextchannel=facb83453d4a3 210VgnVCM100000b92ca60aRCRD.

[45] Pew Hispanic Center, 2007 National Survey of Latinos: As Illegal Immigration Issue Heats Up, Hispanics Feel a Chill, Pew Hispanic Center, Washington, DC, USA, 2007.

[46] S. A. Kossoudji, "Playing cat and mouse at the US-Mexican border," Demography, vol. 29, no. 2, pp. 159-180, 1992.

[47] P. V. Schaeffer, "Refugees: on the economics of political migration," International Migration, vol. 48, no. 1, pp. 1-22, 2010.

[48] A. A. Pena, "Legalization and immigrants in U.S. agriculture," The B.E. Journal of Economic Analysis \& Policy, vol. 10, no. 1, article 7, 2010. 


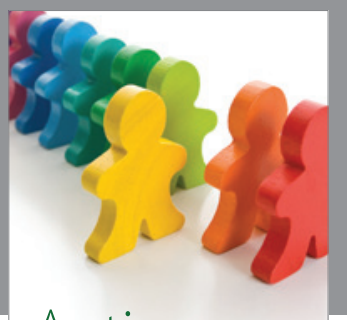

Autism

Research and Treatment
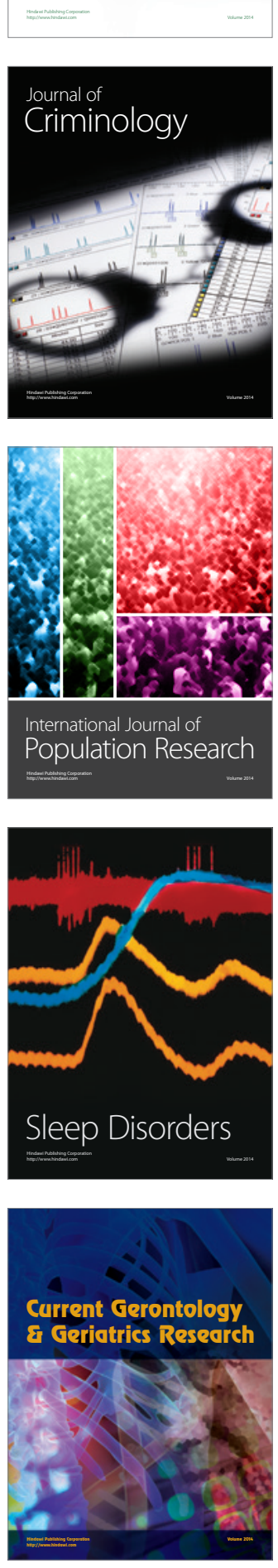
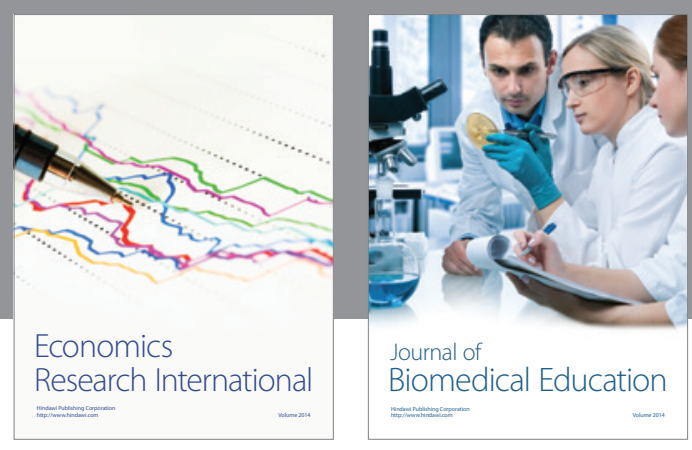

Journal of

Biomedical Education

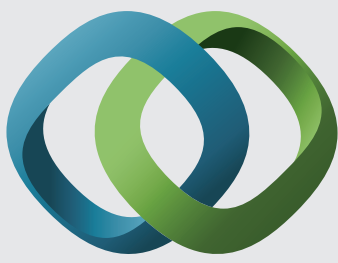

\section{Hindawi}

Submit your manuscripts at

http://www.hindawi.com
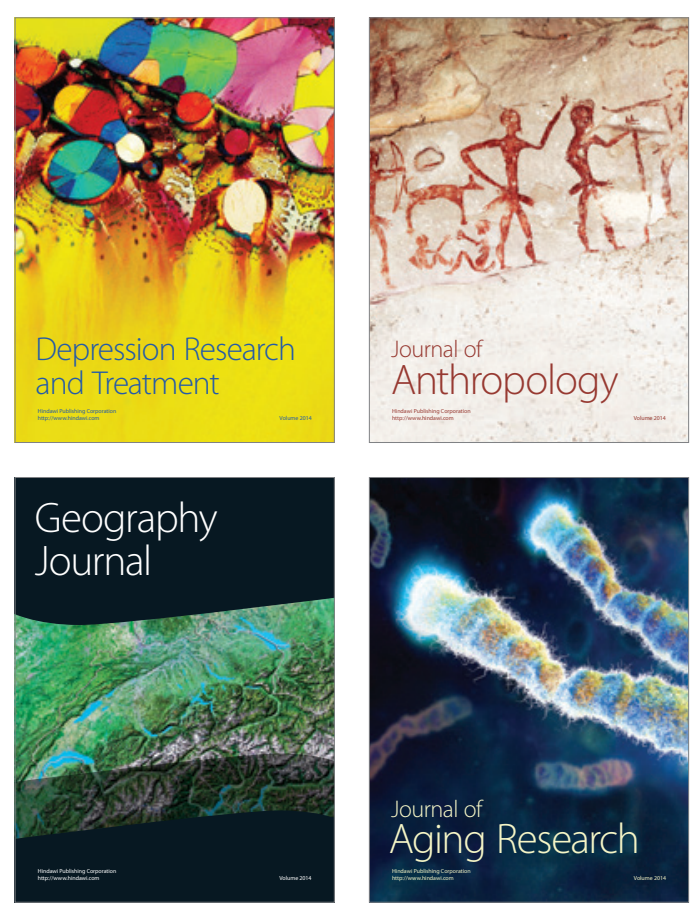

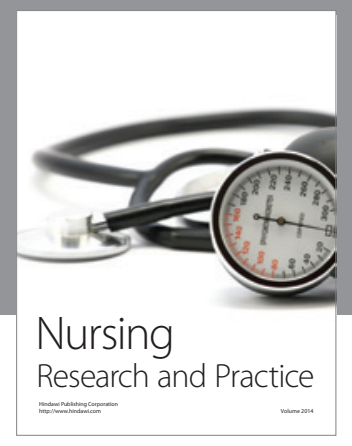

Nursing

Research and Practice

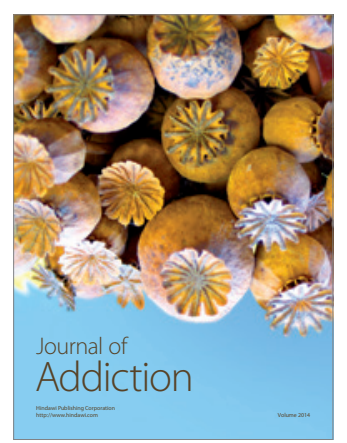

Child Development

Research

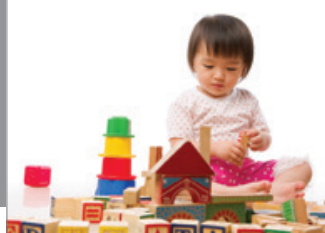

迥
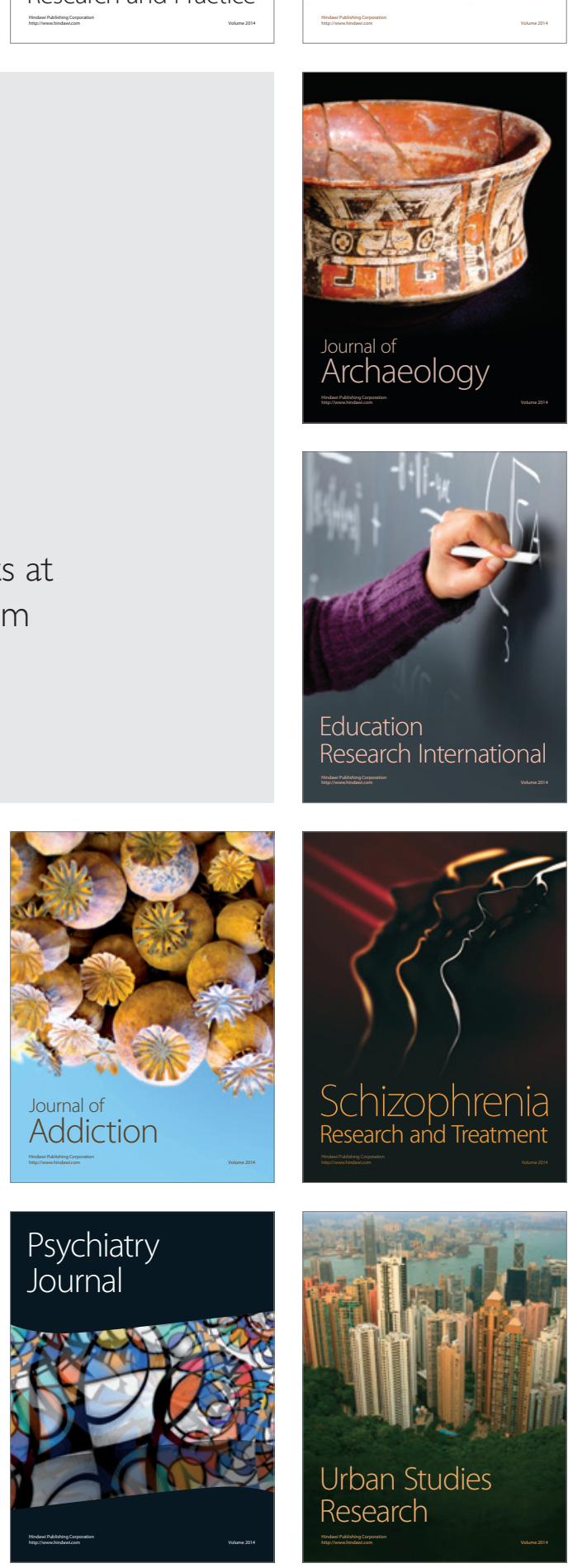